\title{
Integrasi Model Pembelajaran Inkuiri dan Kooperatif Tipe Jigsaw untuk Peningkatan Pemahaman dan Partisipasi Siswa.
}

\author{
Sri Santiawati ${ }^{\left.a^{*}\right)}$ \\ a) Universitas Terbuka, Kota Bogor, Indonesia \\ ${ }^{*}$ e-mail korespondensi: srisantiawatiut@gmail.com
}

\section{Riwayat Artikel}

diterima 03 Juni 2021

direvisi 25 Juni 2021

disetujui 28 Juli 2021

\begin{abstract}
Abstrak.
Tujuan dari penelitian ini untuk mengetahui (1) Kemampuan pemahaman siswa yang memperoleh model integrasi pembelajaran inkuiri dan kooperatif tipe jigsaw daripada pembelajaran konvensional, (2) Peningkatan pemahaman siswa yang memperoleh model integrasi pembelajaran inkuiri dan kooperatif tipe jigsaw daripada pembelajaran konvensional, (3) Partisipasi siswa yang memperoleh model integrasi pembelajaran inkuiri dan kooperatif tipe jigsaw daripada pembelajaran konvensional. Desain dalam penelitian ini adalah rancangan kelompok-kontrol (pretes dan postes) nonekuivalen (nonequivalent [pre-test dan post-test] control-group design). Teknik analisis yaitu analisis prasyarat yaitu normalitas, homogenitas, dan uji-t. Berdasarkan analisis data disimpulkan bahwa (1) pemahaman siswa yang memperoleh integrasi model pembelajaran inkuiri dan kooperatif Jigsaw lebih baik daripada pemahaman siswa yang memperoleh pembelajaran konvensional, (2) peningkatan pemahaman siswa yang memperoleh integrasi model pembelajaran inkuiri dan kooperatif Jigsaw lebih baik daripada peningkatan pemahaman siswa yang memperoleh pembelajaran konvensional, (3) partisipasi siswa yang memperoleh model integrasi pembelajaran inkuiri dan kooperatif Jigsaw lebih baik daripada partisipasi siswa yang memperoleh pembelajaran konvensional.
\end{abstract}

Kata Kunci: integrasi pembelajaran inkuiri dan jigsaw; partisipasi siswa; pemahaman siswa

\begin{abstract}
The aims of the research are to find out (1) the comprehension ability of sfudents who get the integration of learning model of Inquiry and Jigsaw compared to those who get convensional model of learning, (2) the comprehension improvement of students who get the integration of learning model of Inquiry and Jigsaw compared to those who get convensional model of learning, (3) the participation of students who get the integration of learning model of Inquiry and Jigsaw compared to those who get convensional model of learning. The design of the research was non equivalent pre-test and post-test control group design. Analysis technique is prerequisite analysis, they are normality, homogenity and T-test. Based on data analysis, the writer concludes that (1) the comptehension of students who get the integration of learning model of Inquiry and Jigsaw is better than the comprehension of students who get convensional model of learning, (2) the comprehension improvement of students who get the integration of learning model of Inquiry and Jigsaw is better than the comprehension improvement of students who get convensional model of learning, (3) the participation of students who get the integration of learning model of Inquiry and Jigsaw is better than the participation of students who get convensional model of learning.
\end{abstract}

Keywords: integration of learning model of inquiry and jigsaw; student participation; student comprehension.

\section{PENDAHULUAN}

Berdasarkan data UNESCO mengenai Global Education Monitoring (GEM) Report 2016, mutu pendidikan di Indonesia menduduki peringkat ke-10 dari 14 negara berkembang. Sementara kualitas guru sebagai komponen penting dalam pendidikan tergolong memprihatinkan, yaitu berada di posisi ke-14 dari 14 negara berkembang di dunia.

Selain keteladanan, penyebab lain rendahnya mutu pendidikan di Indonesia yaitu terkait efektivitas, efisiensi, dan standarisasi pengajaran. Kreatifitas guru dalam membimbing siswa perlu ditingkatkan, salah satunya dengan mengacu pada kurikulum yang berlaku di Indonesia saat ini.

Kondisi pendidikan di Indonesia yang menyatakan bahwa peringkat Indonesia dalam bidang pendidikan berada di posisi ketujuh di ASEAN, hal ini berdasarkan penelitian yang dilakukan oleh Human Development Reports (2017).
Singapura meraih skor tertinggi, yaitu sebesar 0,832 . Peringkat kedua diduduki oleh Malaysia $(0,719)$ dan diikuti oleh Brunei Darussalam (0,704). Pada posisi keempat ada Thailand dan Filipina, keduanya sama-sama memiliki skor 0,661 . Sedangkan Indonesia menempati peringkat ketujuh dengan skor 0,622.

Salah satu kegiatan dalam pendidikan di sekolah yaitu pembelajaran. Pembelajaran adalah proses perubahan tingkah laku siswa dan proses interaksi antara siswa dengan lingkungan belajar yang difasilitasi oleh guru. Pembelajaran juga didefinisikan sebagai perubahan perilaku manusia karena adanya pengalaman atau masukan informasi. Aspek pembelajaran yang paling penting adalah perubahan. Pembelajaran juga dicapai melalui eksperimen-eksperimen individu yang memungkinkan pengetahuan masa lalu berintegrasi dengan pengetahuan saat ini untuk memunculkan 
pengetahuan baru (Smith, 2008). Di dalam kegiatan pembelajaran ada interaksi antara guru dengan peserta didik, dimana antara keduanya harus terjalin hubungan yang saling mendukung antara satu dengan yang lainnya.

Guru adalah pendamping dalam proses pembelajaran dan pencipta kondisi lingkungan belajar. Keberhasilan suatu proses pembelajaran tidak terlepas dari kemampuan guru dalam mengembangkan model pembelajaran yang berorientasi pada peningkatan intensitas keterlibatan peserta didik secara efektif didalam proses pembelajaran. Pembelajaran di kelas dinyatakan berkualitas apabila guru yang mengajar dapat menciptakan kondisi belajar atau lingkungan belajar yang kondusif sehingga semua peserta didik terlibat aktif dalam proses pembelajaran. Kualitas proses pembelajaran juga dipengaruhi oleh perencanaan pembelajaran yang dibuat oleh guru, penerapan rencana pembelajaran di kelas, serta evaluasi yang akan dilakukan guru setelah pembelajaran selesai. Hal tersebut sejalan dengan pendapat Rini Kristiantari (2014) yang menyatakan bahwa peran guru di dalam proses pembelajaran tetaplah menjadi kunci sukses sebuah pendidikan.

Faktanya, saat ini sebagian besar pola pembelajaran masih bersifat transmisif, guru hanya mentransfer konsep secara langsung pada siswa. Dalam pandangan ini, siswa secara pasif "menyerap" struktur pengetahuan yang diberikan guru atau yang terdapat dalam buku pelajaran. Pembelajaran hanya sekedar penyampaian fakta, konsep, prinsip dan keterampilan kepada siswa (Clements \& Battista, 2001 dalam Trianto, 2014).

Untuk meningkatkan pemahaman dan partisipasi peserta didik dalam kegiatan pembelajaran, maka seorang guru harus bisa memotivasi peserta didik melalui kegiatan pembelajaran yang aktif. Teori konstruktivisme merupakan salah satu teori yang melandasi pembelajaran aktif. Pada dasarnya pendekatan konstruktivisme dalam belajar adalah suatu pendekatan dimana siswa secara individu menemukan dan mentransformasikan informasi yang kompleks, memeriksa informasi dengan aturan yang jelas dan merevisinya bila perlu. Konstruktivisme adalah paradigma pembelajaran yang menggambarkan proses pembentukan pengetahuan (Qais, 2009 : 11). Huang (2006: 11 dalam Qais, 2017) menguraikan metode belajar konstruktivis sebagai berikut: Pembelajaran konstruktivis adalah mengonstruksi pengetahuan, bukan menerimanya. Pembelajaran konstruktivis adalah memahami dan menerapkan, bukan mengingat. Pembelajaran konstruktivis adalah berpikir dan menganalisis, bukan menghimpun dan menghafal. Pembelajaran konstruktivis adalah bersikap aktif bukan pasif. Model pembelajaran yang mengarahkan pada pembelajaran konstruktivisme diantaranya model pembelajaran inkuiri dan model pembelajaran kooperatif tipe jigsaw.

Dalam penelitian ini, peneliti menggunakan dua model pembelajaran, yaitu model pembelajaran inkuiri dan model pembelajaran kooperatif tipe jigsaw. Dengan menggunakan kedua model pembelajaran ini diduga dapat meningkatkan motivasi belajar siswa, sehingga partisipasi dalam kegiatan pembelajaran dapat terlihat dan akhirnya dapat memudahkan siswa dalam memahami materi pelajaran. Dengan demikian, hasil belajar siswa pun bisa lebih optimal.

Model pembelajaran inkuiri adalah model pembelajaran yang berusaha menempatkan dasar dan mengembangkan cara berfikir ilmiah. Dalam penerapan model ini peserta didik dituntut untuk lebih banyak belajar secara mandiri dan berusaha mengembangkan kreatifitas dalam pengembangan masalah yang dihadapinya sendiri. Model pembelajaran inkuiri akan menciptakan kondisi belajar yang efektif dan kondusif, serta mempermudah dan memperlancar kegiatan belajar mengajar (Sudjana, 2004). Model inkuiri ini merupakan suatu model yang mampu merangsang peserta didik untuk berfikir, menganalisa suatu persoalan sehingga menemukan pemecahannya. Model ini membina kecakapan untuk melihat alasan-alasan yang tepat dari suatu persoalan, sehingga pada akhirnya dapat ditemukan bagaimana cara penyelesaiannya.

Pembelajaran Jigsaw merupakan tipe pembelajaran kooperatif yang dikembangkan oleh seorang tokoh bernama Elliot Aronson's. Model pembelajaran ini dirancang untuk meningkatkan rasa tanggung jawab siswa terhadap pembelajarannya sendiri dan juga pembelajaran orang lain. Siswa tidak hanya mempelajari materi yang diberikan, tetapi mereka juga harus siap memberikan dan mengajarkan materi tersebut kepada kelompoknya. Pada model pembelajaran jigsaw ini keaktifan peserta didik (student centered) sangat dibutuhkan, dengan dibentuknya kelompok-kelompok kecil yang beranggotakan 4-6 orang.

Berdasarkan uraian tersebut, penelitian ini bertujuan untuk (1) menganalisis kemampuan pemahaman siswa yang memperoleh model integrasi pembelajaran inkuiri dan kooperatif tipe jigsaw daripada pembelajaran konvensional; (2) menganalisis peningkatan pemahaman siswa yang memperoleh model integrasi pembelajaran inkuiri dan kooperatif tipe jigsaw daripada pembelajaran konvensional; (3) menganalisis partisipasi siswa yang memperoleh model integrasi pembelajaran inkuiri dan kooperatif tipe jigsaw daripada pembelajaran konvensional.

\section{METODE PENELITIAN}

Metode penelitian yang digunakan dalam penelitian ini adalah metode eksperimen dengan jenis rancangan Eksperimental Semu (Quasi-Experimental Research). Dalam penelitian eksperimen ini, peneliti menggunakan kelompok kontrol dan kelompok eksperimen. Tujuannya adalah untuk memperoleh informasi yang merupakan perkiraan bagi informasi yang dapat diperoleh dengan eksperimen yang sebenarnya dalam keadaan tidak memungkinkan untuk mengontrol dan atau memanipulasi semua variabel yang relevan. Peneliti ingin meneliti pengaruh integrasi model pembelajaran inkuiri dan kooperatif tipe jigsaw terhadap peningkatan pemahaman dan partisipasi siswa dalam kegiatan pembelajaran.

Penelitian dilakukan dengan mengambil dua kelompok sampel secara acak dalam bentuk kelas. Kelas eksperimen diterapkan pembelajaran menggunakan model pembelajaran inkuiri dan kooperatif tipe jigsaw dan kelas kontrol menggunakan pembelajaran konvensional. Materi 
pembelajaran yang diterapkan yaitu pembelajaran tematik. Hasil dari kedua kelompok tersebut akan dikaji dan dianalisa secara statistik parametrik untuk data yang memenuhi prasyarat normal dan homogen. Data diperoleh dari pretes, postes, dan skor gain pemahaman hasil penerapan model pembelajaran inkuiri jigsaw dan angket partisipasi siswa dalam kegiatan pembelajaran.

Desain atau rancangan eksperimen yang digunakan dalam penelitian ini adalah rancangan kelompok-kontrol (pretes dan postes) nonekuivalen (nonequivalent [pre-test dan post-test] control-group design). Berikut ini disajikan tabel desain penelitian nonequivalent (pre-test dan post-test) control-group design.

TABEL 1. Desain Penelitian

\begin{tabular}{llll}
\hline \multicolumn{1}{c}{ Kelas } & Tes Awal & Perlakuan & Tes Akhir \\
\hline Kelas & tes & Inkuiri dan & tes \\
eksperimen & awal/pretes & kooperatif & akhir/postes \\
Kelas & tes & & tes \\
kontrol & awal/pretes & & akhir/postes \\
\hline
\end{tabular}

Populasi dalam penelitian ini adalah seluruh siswa kelas IV gugus Gadung kecamatan Karangtengah Kabupaten Cianjur tahun pelajaran 2019-2020 yang terdiri dari 11 sekolah. Sampel dalam penelitian ini ditentukan dengan teknik purposive sampling, dan peneliti menetapkan SD Negeri Sukataris Kecamatan Karangtengah Kabupaten Cianjur sebagai sampel penelitian. Dua kelas yang terpilih sebagai sampel yaitu siswa kelas IV SD Negeri Sukataris Kecamatan Karangtengah Kabupaten Cianjur yang terdiri dari kelas IVA dan IVB. Kelas IVA berjumlah 30 siswa yang terdiri dari 12 siswa laki-laki dan 18 siswa perempuan, sedangkan kelas IVB berjumlah 29 siswa yang terdiri dari 11 siswa laki-laki dan 18 siswa perempuan.

Instrumen yang digunakan dalam penelitian ini berupa instrumen tes, yaitu tes tulis pemahaman siswa, lembar observasi dan angket partisipasi siswa. Tes tulis berupa penilaian terhadap pemahaman siswa terdiri dari tes awal untuk mengetahui sejauh mana pengetahuan awal peserta didik, sebelum diterapkan model pembelajaran inkuiri jigsaw dan tes akhir untuk mengetahui sejauh mana peningkatan pemahaman pada materi pembelajaran setelah diterapkan model pembelajaran inkuiri dan jigsaw. Lembar observasi untuk mengukur aktivitas peserta didik yang terjadi dalam proses pembelajaran. Sedangkan angket berupa respon siswa bertujuan untuk memperoleh informasi mengenai pendapat siswa tentang proses pembelajaran menggunakan model pembelajaran inkuiri-jigsaw.

\section{HASIL DAN PEMBAHASAN}

\section{A. Hasil Penelitian}

Data yang diperoleh dalam penelitian ini adalah data kuantitatif dan data kualitatif, data tersebut bertujuan untuk menemukan jawaban dari rumusan masalah yang telah ditentukan sebelumnya. Data kuantitatif diperoleh dari pretes pemahaman siswa yang dilakukan sebelum perlakuan diberikan pada kelas eksperimen dan kelas kontrol. Data postes diberikan setelah diberikan perlakuan terhadap siswa berupa perlakuan integrasi model pembelajaran inkuiri dan kooperatif tipe jigsaw pada kelas eksperimen dan pembelajaran konvesional pada kelas kontrol. Data kualitatif diperoleh dari angket yang diberikan kepada siswa dan lembar observasi siswa untuk mengetahui perbedaan partisipasi siswa dalam pembelajaran dengan menggunakan integrasi pembelajaran inkuiri dan kooperatif tipe jigsaw.

\section{1) Data Kuantitatif}

\section{a) Data Pretes Pemahaman Siswa}

Dari hasil pengumpulan data pretes pemahaman siswa, diperoleh jumlah skor pada kelas eksperimen dan kelas kontrol hampir sama, selanjutnya skor diolah untuk diketahui data deskripsi dengan menggunakan program SPSS Statistic 25.0 for Windows untuk masing-masing kelas. Diperoleh data deskripsi skor pretes pemahaman siswa seperti nilai minimum, nilai maksimum, rata-rata, dan simpangan baku dapat dilihat di Tabel 2.

Tabel 2. Data Deskripsi Skor Pretes Pemahaman Siswa pada Kelas Eksperimen dan Kontrol

\begin{tabular}{|c|c|c|c|}
\hline \multicolumn{2}{|c|}{ Statistics } & \multirow{2}{*}{$\begin{array}{c}\begin{array}{c}\text { Kelas } \\
\text { Eksperimen }\end{array} \\
14.6000\end{array}$} & \multirow{2}{*}{$\begin{array}{c}\begin{array}{c}\text { Kelas } \\
\text { Kontrol }\end{array} \\
15.3448\end{array}$} \\
\hline Mean & & & \\
\hline Median & & 14.5000 & 16.0000 \\
\hline Mode & & $13.00^{\mathrm{a}}$ & 16.00 \\
\hline Std. Deviat & & 2.37225 & 2.88191 \\
\hline Variance & & 5.628 & 8.305 \\
\hline Minimum & & 10.00 & 9.00 \\
\hline Maximum & & 19.00 & 21.00 \\
\hline Sum & & 438.00 & 445.00 \\
\hline \multirow[t]{3}{*}{ Percentiles } & 25 & 13.5000 & \\
\hline & 50 & 16.0000 & \\
\hline & 75 & 17.5000 & \\
\hline
\end{tabular}

a. Multiple modes exist. The smallest value is shown

Berdasarkan Tabel 3 dapat dilihat bahwa rata-rata skor pemahaman siswa pada eksperimen sebesar 14,60 karakter; simpangan baku 2,37; median sebesar 14,50; modus sebesar 13,00; nilai minimum 10,0 dan nilai maksimum 19,0. Sedangkan rata-rata skor pemahaman siswa pada kelas kontrol sebesar 15,34 karakter; simpangan baku 2,88; median sebesar 16,00; modus sebesar 16,00; nilai minimum 9,0 dan nilai maksimum 21

\section{b) Data Postes Pemahaman Siswa}

Dari hasil pengumpulan data postes pemahaman siswa, diperoleh jumlah skor postes pemahaman siswa pada kelas eksperimen dan kelas kontrol berbeda, selanjutnya skor diolah untuk diketahui data deskripsi dengan program SPSS Statistic 25.0 for Windows untuk masing-masing kelas. Diperoleh data deskripsi postes pemahaan siswa yaitu nilai minimum, nilai maksimum, rata-rata, median, modus, dan simpangan baku dapat dilihat di Tabel 3. 
Tabel 3. Data Deskripsi Skor Postes Pemahaman Siswa pada Kelas Eksperimen dan Kontrol

\begin{tabular}{|c|c|c|c|}
\hline \multicolumn{2}{|l|}{ Statistic } & $\begin{array}{c}\text { Kelas } \\
\text { eksperimen }\end{array}$ & Kelas kontrol \\
\hline Mean & & 25.1667 & 18.2069 \\
\hline Median & & 25.0000 & 18.0000 \\
\hline Mode & & 26.00 & $18.00^{\mathrm{a}}$ \\
\hline Std. Deviation & & 2.33538 & 3.02819 \\
\hline Variance & & 5.454 & 9.170 \\
\hline Minimum & & 21.00 & 12.00 \\
\hline Maximum & & 30.00 & 24.00 \\
\hline Sum & & 755.00 & 528.00 \\
\hline \multirow[t]{3}{*}{ Percentiles } & 25 & 23.0000 & 16.0000 \\
\hline & 50 & 25.0000 & 18.0000 \\
\hline & 75 & 27.0000 & 20.5000 \\
\hline
\end{tabular}

a. Multiple modes exist. The smallest value is shown

Pada Tabel 3 dapat dilihat bahwa rata-rata skor postes pemahaman siswa pada kelas eksperimen sebesar 25,667 karakter; simpangan baku 2,335; median sebesar 25,00; modus sebesar 26,00; nilai minimum 11,00 dan nilai maksimum 30,00. Sedangkan rata-rata skor postes pemahaman siswa pada kelas kontrol sebesar 18,207; simpangan baku 3,028; median sebesar 18,00; modus sebesar 18,00; nilai minimum 12,0 dan nilai maksimum 24,00.

\section{c) Data Skor Gain Pemahaman Siswa}

Pengujian hipotesis yang kedua bertujuan untuk melihat peningkatan pemahaman siswa antara kelas eksperimen dengan kelas control. Berdasarkan hasil perhitungan skor gain pemahaman siswa, diperoleh data deskripsi skor gain pemahaman siswa sebagai berikut ini.

Tabel 4 Data Deskripsi Skor Gain Pemahaman

\begin{tabular}{|c|c|c|c|}
\hline \multicolumn{2}{|c|}{ Statistik } & Eksperimen & Kontrol \\
\hline \multicolumn{2}{|c|}{ Mean } & 0,6437 & 0,4169 \\
\hline \multicolumn{2}{|c|}{ Median } & 0,6900 & 0,2100 \\
\hline \multicolumn{2}{|c|}{ Mode } & 0,69 & 0,17 \\
\hline \multicolumn{2}{|c|}{ Std. Deviation } & 0,20372 & 2,78122 \\
\hline \multicolumn{2}{|c|}{ Variance } & 0,041 & 7,735 \\
\hline \multicolumn{2}{|c|}{ Minimum } & 0,10 & 0,13 \\
\hline \multicolumn{2}{|c|}{ Maximum } & 0,94 & 0,90 \\
\hline \multicolumn{2}{|c|}{ Sum } & 19,31 & 12,09 \\
\hline \multirow{3}{*}{ Percentiles } & 25 & 0,5225 & 0,1450 \\
\hline & 50 & 0,6900 & 0,2100 \\
\hline & 75 & 0,8050 & 0,3700 \\
\hline
\end{tabular}

a. Multiple modes exist. The smallest value is shown

Pada Tabel 4 dapat dilihat bahwa rata-rata skor gain pemahaman siswa pada kelas eksperimen sebesar 0,6437; simpangan baku 0,2037; median sebesar 0,6900; modus sebesar 0,69; nilai minimum 0,10 dan nilai maksimum 0,94. Sedangkan rata-rata skor gain pemahaman siswa pada kelas kontrol sebesar 0,4169; simpangan baku 2,78122; median sebesar 0,2100; modus sebesar 2,7812; nilai minimum 13,00 dan nilai maksimum 0,90 .

\section{2) Data Kualitatif}

Diperoleh data deskripsi skor angket partisipasi seperti nilai minimum, nilai maksimum, rata-rata, median, modus, dan simpangan baku. Berdasarkan hasil perhitungan skor gain pemahaman siswa, diperoleh data deskripsi skor angket partisipasi siswa sebagai berikut.

Tabel 5 Deskripsi Hasil Angket Partisipasi Siswa

\begin{tabular}{|c|c|c|c|}
\hline \multicolumn{2}{|c|}{ Statistics } & Eksperimen & Kontrol \\
\hline \multicolumn{2}{|l|}{ Mean } & 87.8000 & 72.5172 \\
\hline \multicolumn{2}{|l|}{ Median } & 88.0000 & 73.0000 \\
\hline \multicolumn{2}{|l|}{ Mode } & 88.00 & 71.00 \\
\hline \multicolumn{2}{|c|}{ Std. Deviation } & 3.03315 & 4.91805 \\
\hline \multicolumn{2}{|c|}{ Variance } & 9.200 & 24.187 \\
\hline \multicolumn{2}{|l|}{ Minimum } & 83.00 & 60.00 \\
\hline \multicolumn{2}{|l|}{ Maximum } & 95.00 & 82.00 \\
\hline \multicolumn{2}{|l|}{ Sum } & 2634.00 & 2103.00 \\
\hline \multirow[t]{3}{*}{ Percentiles } & 25 & 85.0000 & 70.0000 \\
\hline & 50 & 88.0000 & 73.0000 \\
\hline & 75 & 89.2500 & 76.0000 \\
\hline
\end{tabular}

Pada Tabel 5 dapat dilihat bahwa rata-rata skor angket partisipasi siswa pada kelas eksperimen sebesar 87,80; simpangan baku 3,033; median sebesar 88,00; modus sebesar 88,00 ; nilai minimum 83,00 dan nilai maksimum 95,0. Sedangkan rata-rata skor angket partisipasi siswa pada kelas kontrol sebesar 72,517; simpangan baku 4,918; median sebesar 73,00; modus sebesar 71,00; nilai minimum 60,00 dan nilai maksimum 82,00 . Hal tersebut menunjukkan skor angket partisipasi siswa pada kelas eksperimen lebih tinggi daripada skor angket partisipasi siswa pada kelas kontrol.

\section{B. Pembahasan}

Sesuai hasil pengujian data pretes pemahaman siswa memiliki kemampuan pemahaman awal yang berdistribusi normal dan homogen. Selanjutnya untuk melihat perbedaan pemahaman siswa antara yang mendapatkan model integrasi pembelajaran inkuiri dan kooperatif tipe jigsaw dengan siswa yang mendapatkan pembelajaran konvensional diperoleh dari hasil uji perbedaan rata-rata dengan menggunakan uji t skor postes pemahaman siswa. Dapat disimpulkan bahwa pemahaman siswa antara yang mendapatkan model integrasi pembelajaran inkuiri dan kooperatif tipe jigsaw lebih baik dari pemahaman siswa yang mendapatkan pembelajaran konvensional. Hasil uji t hitung sebesar 10,011 lebih dari t tabel $=1672$, ini berarti pemahaman siswa yang mendapatkan model integrasi pembelajaran inkuiri dan kooperatif tipe jigsaw berbeda dengan pemahaman siswa yang mendapatkan pembelajaran konvensional. Dan dikatakan pemahaman siswa antara siswa yang mendapatkan model integrasi pembelajaran inkuiri dan kooperatif tipe jigsaw lebih baik dari pemahaman siswa yang mendapatkan pembelajaran konvensional dapat dilihat dari nilai rata-rata antar kedua kelas tersebut. Nilai rata-rata pada kelas yang mendapatkan model integrasi pembelajaran inkuiri dan kooperatif tipe 
jigsaw sebesar 25,1667 lebih tinggi daripada nilai rata-rata pemahaman siswa yang mendapatkan pembelajaran konvensional sebesar 18,2067.

Dari hasil penelitian digambarkan bahwa pemahaman siswa sebagian besar sudah baik. Hal tersebut disebabkan aspek yang di amati karena siswa menjadi pelaku dan berperan aktif dalam proses belajar mengajar (Murwani, 2006). Beberapa faktor antara lain forum diskusi. Dalam diskusi siswa dihadapkan dengan pendapat-pendapat teman sekelasnya. Dengan demikian siswa dilatih untuk berpikir bagaimana mereka mempertahankan pendapatnya dan bagaimana mereka mengungkapkan pendapatnya. Hal ini sesuai dengan Koes (2003) bahwa salah satu keuntungan pembelajaran menggunakan metode inkuiri adalah dapat mengembangkan bakat keterampilan individu dalam diskusi. Namun berbeda pendapat dengan Prambudi (2010) bahwa kelemahan pembelajaran inkuiri sulit dalam merencanakan pembelajaran karena terbentur dengan kebiasaan siswa dalam belajar sebelumnya. Siswa yang tidak terbiasa dengan proses menemukan masalah dan solusi dalam pembelajarannya, guru akan kesulitan dalam mengarahkan dan merencanakan pembelajaran sehingga pembelajaran tidak berjalan dengan lancar dan memerlukan waktu yang cukup lama. Hal tersebut diungkapkan pula oleh Sanajaya (2010) bahwa kadangkadang dalam mengimplementasikan pembelajaran inkuiri memerlukan waktu yang panjang sehingga sering guru merasa kesulitan dalam menyesuaikannya dengan waktu yang telah ditentukan.

Berdasarkan analisis uji perbedaan skor gain dengan menggunakan uji t data skor gain, diperoleh nilai signifikan sebesar 0,000 kurang dari 0,05 atau dapat dilihat pada hasil uji thitung sebesar 10,814 lebih dari ttabel 1,672; artinya terdapat perbedaan pemahaman siswa pada kelas yang mendapatkan model integrasi pembelajaran inkuiri dan kooperatif tipe jigsaw dengan pemahaman siswa yang mendapatkan model pembelajaran konvensional. Selanjutnya jika dilihat pada nilai rata-rata skor gain pada kedua kelas juga berbeda, yaitu nilai rata-rata pada kelas yang mendapatkan model integrasi inkuiri dan kooperatif jigsaw sebesar 0,6437 sedangkan nilai rata-rata pada kelas konvensional sebesar 0,4169; artinya pemahaman siswa yang mendapatkan model integrasi pembelajaran inkuiri dan kooperatif tipe jigsaw lebih baik daripada pemahaman siswa yang mendapatkan model pembelajaran konvensional. Hal ini disebabkan oleh perbedaan perlakuan pada kedua kelas saat pembelajaran berlangsung. Pada kelas yang mendapatkan model integrasi pembelajaran inkuiri dan kooperatif tipe jigsaw, siswa belajar lebih bermakna karena siswa melakukan pembelajaran dengan menemukan sendiri materi pelajaran dengan cara berkelompok sesuai langkah-langkah pembelajaran kooperatif jigsaw.

Setelah analisis data skor gain, selanjutnya mengkaji skor angket partisipasi siswa untuk mengetahui perbedaan partisipasi siswa pada kelas yang mendapatkan model integrasi pembelajaran inkuiri dan kooperatif tipe jigsaw dengan partisipasi siswa yang mendapatkan pembelajaran konvensional. Partisipasi siswa mana yang lebih baik diantara kedua kelas tersebut. Berdasarkan hasil uji t skor angket partisipasi siswa diperoleh thitung sebesar 14,420 lebih dari t tabel sebesar 1,672. Selanjutnya diperoleh nilai rata-rata partisipasi siswa pada kelas yang mendapatkan model integrasi pembelajaran inkuiri dan kooperatif tipe jigsaw sebesar 87,80 sedangkan nilai rata-raata siswa pada kelas pembelajaran konvensional sebesar 75,52. Maka rata-rata siswa pada kelas model integrasi pembelajaran inkuiri dan kooperatif tipe jigsaw lebih tinggi daripada rata-rata pada siswa yang memperoleh pembelajaran konvensional.

Sejalan dengan penelitian yang dilakukan oleh Yohana Octavany, dkk. (2018) dengan judul: "Efektivitas Pendekatan Inkuiri dan Model Jigsaw (PI-MJ) terhadap Minat Belajar Siswa Kelas 4 SD”. Berdasarkan penelitian ini pembelajaran dengan PI-MJ membuat siswa berperan aktif dalam kegiatan pembelajaran. Siswa tidak hanya duduk diam mendengarkan penjelasan dari guru, namun siswa mencari tahu pengetahuan yang ingin mereka dapatkan dan membaginya kepada teman yang lain. Penelitian ini menunjukkan keefektifan pembelajaran dengan menggunakan pendekatan inkuiri dan model jigsaw terhadap minat belajar siswa kelas 4 SD.

Selain itu, penelitan yang dilakukan Afazr, Gusrayani, dan Sunarya (2016) membuktikan bahwa permasalahan siswa yang mampu ditangani oleh model pembelajaran jigsaw seperti siswa yang pasif adalah dengan adanya langkah pembelajaran pembentukan kelompok asal dan kelompok ahli. Pada langkah membentuk kelompok asal, setiap siswa akan ditugaskan untuk mengerjakan soal-soal yang diberikan guru kepadanya. Siswa secara individu mengerjakan soal-soal tersebut berdasarkan kemampuannya sendiri dan kemudian hasil pekerjaannya itu didiskusikan dengan rekan-rekannya di kelompok asal. Setelah selesai berdiskusi dengan kelompok asal, siswa harus mendiskusikan soal tersebut dengan kelompok ahli. Di kelompok ahli ini, siswa dituntut untuk mengeluarkan pendapatnya pada saat berdiskusi dengan rekan-rekannya di kelompok ahli. Setelah selesai, siswa kembali ke kelompok asalnya kemudian melaporkan dan mengajarkan penemuannya itu pada rekan-rekannya di kelompok asal. Pada pelaksanaan model pembelajaran jigsaw ini, siswa harus terlibat secara aktif pada seluruh langkahlangkah pembelajaran.

Penelitian lain yang mendukung yaitu penelitian dengan judul "Pengaruh Model Pembelajaran Inkuiri Terbimbing Terhadap Kemampuan Berpikir Kritis IPA SD” dilakukan oleh Mohammad Liwa Ilhamdi, dkk. (2020) di Mataram. Hasil dari penelitian menyimpulkan bahwa model pembelajaran inkuiri terbimbing mempunyai peran penting dalam kegiatan pembelajaran karena dengan menggunakan model pembelajaran ini siswa diajak untuk terus berpartisipasi secara aktif dalam kegiatan belajar. Dengan partisipasi siswa secara aktif dalam proses penyelidikan yang diberikan oleh guru, kemampuan berpikir kritis siswa dapat meningkat dan siswa terbiasa untuk terlatih berpikir secara kritis.

Integrasi model pembelajaran inkuiri dan koopratif jigsaw yang telah dilaksanakan dapat meningkatkan pemahaman dan keaktifan siswa karena dengan menggunakan model pembelajaran ini siswa terlihat lebih aktif dalam belajar, kegiatan belajar lebih menarik dan tidak membosankan. 
Berdasarkan hasil observasi, siswa yang memperoleh integrasi model pembelajaran inkuiri dan koopratif jigsaw, pada umumnya terjadi peningkatan partisipasi siswa yang membuat pemahaman siswa lebih baik. Siswa membangun pengetahuannya sendiri dengan adanya tuntutan untuk bisa membuat pertanyaan sendiri, membuat catatan bermakna dan menjawab pertanyaan yang telah diajukan sendiri. Selain itu, proses ini membuat siswa menjadi lebih aktif dalam belajar dan dengan adanya pengelompokan pula siswa menjadi lebih aktif untuk mengeluarkan ide-ide dan menanggapi ide-ide. McMaster dan Fuchs (2002) menyatakan bahwa penelitian yang dilakukan pada tahun 1990-2000 menunjukkan bahwa pembelajaran kooperatif sangat berpengaruh terhadap prestasi akademik siswa yang mempunyai kesulitan belajar.

Dari hasil penelitian ini sebagaimana telah dikemukakan pada bagian sebelumnya, memberikan gambaran bahwa integrasi model pembelajaran inkuiri dan koopratif jigsaw lebih efektif dalam meningkatkan pemahaman dan partisipasi siswa dalam kegiatan pembelajaran. Penerapan model pembelajaran dengan baik dapat membantu siswa untuk terlibat secara aktif membangun pengetahuannya sendiri. Pada saat pembelajaran berlangsung di dalam kelas, setiap siswa hendaknya terlibat secara aktif dalam membangun sendiri pengetahuannya. Dalam penerapan model pembelajaran inkuiri jigsaw guru hendaknya senantiasa memberikan dorongan kepada siswa, bertindak sebagai fasilitator dan membimbing siswa agar dapat bekerja sama dalam menyelesaikan masalah-masalah yang diberikan berupa masalah/pertanyaan sehingga siswa dapat belajar secara mandiri dan menemukan penyelesaian masalah yang diberikan (Bybee \& Trowbridge, 1990; Arends, 2012).

\section{KESIMPULAN}

Berdasarkan hasil penelitian dan pembahasan, secara umum dapat dibuat kesimpulan hasil penelitian bahwa (1) pada integrasi model pembelajaran inkuiri dan kooperatif Jigsaw dengan rata-rata skor postes pemahaman siswa pada kelas konvensional, diperoleh bahwa pemahaman siswa yang memperoleh integrasi model pembelajaran inkuiri dan kooperatif Jigsaw lebih baik daripada pemahaman siswa yang memperoleh pembelajaran konvensional. (2) pada integrasi model pembelajaran inkuiri dan kooperatif Jigsaw dengan rata-rata skor gain pada kelas konvensional, diperoleh bahwa peningkatan pemahaman siswa yang memperoleh integrasi model pembelajaran inkuiri dan kooperatif Jigsaw lebih baik daripada peningkatan pemahaman siswa yang memperoleh pembelajaran konvensional. (3) diperoleh partisipasi siswa pada kelas integrasi model pembelajaran inkuiri dan kooperatif Jigsaw dengan nilai rata-rata skor partisipasi siswa pada kelas konvensional, diperoleh bahwa partisipasi siswa yang memperoleh model integrasi pembelajaran inkuiri dan kooperatif Jigsaw lebih baik daripada partisipasi siswa yang memperoleh pembelajaran konvensional.

\section{REFERENSI}

Abel, S. and Smith, D. (1994). What is science? Preservice elementary teachers conceptions of the natur of science. International Journal of Science Education 16(4), 475-487.

Arends, R I. (2012). Learning to Teach ninth edition. New York : McGraw-Hill.

Al-tabani, Trianto. (2014). Mendesaian Model Pembelajaran Inovatif, Progresif dan Kontekstual. Surabaya : Prenadamedia Group Buku.

Faryadi, Qais. 2013. Four Phases of DR.Cemerlang's Teaching Method: Application of Keller's ARCS Model. Internasional Journal of Humanities and Socience Invention , 2(2).

Ilhamdi, M.L, Novita, D., Rosyidah, A.N.K. (2020). Jurnal Kontekstual 1(2), pp. 49-57

McMaster, K. N. \& Fuchs, D. (2002). Effect of cooperative learning on the academic achievement of students with learning disabilities: an update of tateyama-sniezek's review. Learning Disabilities Research and Practice. 17 (2). 107-117

Murwani, Elika Dwi. (2006). Peran Guru dalam Membangun Kesadaran Kritis Siswa. Jurnal Pendidikan Penabur 5 (6).

Octavany, Y., Wardani, N.S. dan Prasetyo, T. (2018). Efektivitas Pendekatan Inkuiri dan Model Jigsaw (PIMJ) terhadap Minat Belajar Siswa Kelas 4 SD. Jurnal Pendidikan Berkarakter, 1(1), 226-231.

Prambudi, Kuswandi. (2010). Model Inkuiri Terbimbing. Jakarta : Kencana Prenada. Media Grup.

Sanjaya, W. (2012). Strategi Pembelajaran Berorientasi Standar Pendidikan. Jakarta:Kencana Prenada Media Group.

Setiasih, S.D., Panjaitan, R.L., dan Julia. (2016). Penggunaan Model Inkuiri Untuk Meningkatkan Hasil Belajar Siswa Pada Materi Sifat-sifat Magnet di Kelas V SDN Sukajaya Kecamatan Jatinunggal Kabupaten Sumedang. Jurnal Pena Ilmiah. 1(1), 421-430

Smith, PR. (2008). E-marketing : Excellence, UK: Butterworth-. Heinemann.

Sudjana, Nana. (2004). Dasar-dasar Proses Belajar Mengajar. Bandung :Sinar Baru Algensido Offset.

Suprijono. (2012). Cooperative Learning. Yogyakarta: Pustaka Pelajar.

Surahman. (2017). Implementasi Model Pembelajaran Inkuiri-Jigsaw untuk Meningkatkan Pemahaman Siswa Terhadap Servis Engine di sekolah Menengah Kejuruan (SMK). Diunduh 25 April 2019, dari situs World Wide Web: http://eprints.unm.ac.id/

Trowbridge, L.W \& R.W Bybee. (1990). Becoming a Secondary School Science Teacher. Melbourne : Merill Publishing Company. 